\title{
Non Equivalence at Scientific Terms in Mathematics Bilingual Textbook
}

\author{
Fatin Nadifa $\operatorname{Tarigan}^{1} \&$ Juliana ${ }^{2}$ \\ ${ }^{1}$ Universitas Pembinaan Masyarakat Indonesia \& ${ }^{2}$ Universitas Potensi Utama
}

\begin{tabular}{|c|c|}
\hline ARTICLE INFO & \multirow{11}{*}{$\begin{array}{l}\text { ABSTRACT } \\
\text { This study entails the translation of scientific terms from } \\
\text { English into Indonesian. The objectives of this study are to } \\
\text { investigate the problem of non-equivalence at word level } \\
\text { found in mathematics bilingual textbook and to investigate the } \\
\text { translation strategies used. This study was conducted by using } \\
\text { descriptive qualitative design. The data of this study were } 89 \\
\text { words and phrases containing scientific terms. The data were } \\
\text { collected through documentary technique. The technique of } \\
\text { data analysis was interactive model. The finding of this study } \\
\text { revealed that there were five problems of non-equivalence at } \\
\text { scientific terms found in mathematics bilingual textbook. They } \\
\text { were the source language concept is not lexicalized in the } \\
\text { target language, the source language word is semantically } \\
\text { complex, the source and target language make distinction in } \\
\text { meaning, the target language lacks hyponym, and difference } \\
\text { in form. To solve the problems of non equivalence, it was } \\
\text { found that four translation strategies proposed by Baker were } \\
\text { applicable. }\end{array}$} \\
\hline Article history: & \\
\hline Received Sep 28, 2018 & \\
\hline Revised Jan 02, 2018 & \\
\hline Accepted Jan 02, 2019 & \\
\hline Keywords: & \\
\hline $\begin{array}{l}\text { Translation, } \\
\text { Non Equivalence, } \\
\text { Scientific Terms, } \\
\text { Mathematics }\end{array}$ & \\
\hline Clonflict of Interest: & \\
\hline None & \\
\hline Funding: & \\
\hline None & \\
\hline
\end{tabular}

Corresponding Author: Fatin Nadifa Tarigan, lecturer at Universitas Pembinaan Masyarakat Indonesia. Medan, Indonesia. Email: fatinnadifa@yahoo.com Tel. +62 8566241834.

Copyright $@$ C Association of Language Teachers in Southeast Asia. All rights reserved

\section{INTRODUCTION \\ 1.1 Background of Study}

Meaning is the main problem often appears in translation process. The meaning of a given word or set of words can be said as the contribution if the word or phrase can make the meaning or function of the whole sentences or linguistic utterances. The meaning of a given word is translated not only by the external object or idea that particular word is supposed to, but also by the use of that particular word or phrase in a particular way, in a particular context and in a particular effect. Therefore, various aspects are involved in the process of translation to rendering the meaning.

Fixing a specific meaning to words needs some considerations of equivalence. The main consideration is related to the accuracy, clarity and naturalness of the meaning, ideas, or messages of the translation. In addition, internal and external factors that attached to the word and text play important role. As Newmark (1988:4) states that the meaning of a text is influenced by four factors from the source text side, they are the factors of the writer, the target text norm, the culture of the source text, and setting (the place, time and format of the written text are read). In terms of the target text, the text is influenced by meaningful relationship factors, source text norms, culture that underlies source language and settings. If those factors are not considered in translating, the problem of non equivalence will occur.

The problem of non-equivalence can be faced by the translator in various kind of text. It can be 
economic text, medical text, politic text and scientific text. Each kind of text has its own characteristic which causes hardness for the translator to transfer the meaning. One of them is scientific text often read especially by students and academicians for academical purpose. Scientific text was chosen because there were many scientific terms interesting to be researched.

Considering the difficulty of translating terminology and also the internal and external factor attached to the language, translation theorists have put forward some strategies deal with the translation process. Based on Baker (1992), there are eight methods for translating scientific terms. Among them are translation by more general word, translation by more neutral/less expressive word, translation by cultural substitution, translation using a loan word, translation by paraphrase using a related word, translation by paraphrase using unrelated word, translation by ommission, and translation by illustration. In short, this study was conducted to know the problems of non equivalance and strategies used to translate the meaning of term from the source text into target text.

\subsection{Objectives of Study}

In accordance with the background of study, the objective of this study are to investigate the problem of non-equivalence at word level found in mathematics bilingual textbook and to investigate the translation strategies used when translating English scientific terms.

\subsection{Scientific Terms}

The words term, terminology and terminography are interlinked conceptually. A term may constitute of words. Term is a word that contains linguistic characters, and systems (Ananiadou, 1994). In addition, Carolina defines 'term' as sign closely linked to a specialized conceptual content. Modern time 'systematic terminology' is based on an idea of science because of being a well formed language (Popp, 2001).

A term may consists of one or more words (i.e. simple term) or complex term or even contains symbols, and a word; the smallest linguistic unit, conveys a specific meaning, capable of existing as a separate unit in a sentence, whereas 'a written word is marked off by spaces or punctuation marks before and after'. (Pearson, 2008).

Hence, scientific terms are complex terms scientifically bound and only known by scientists specializing in the advanced study of a subject. In bilingual dictionaries, a comprehensive definition and a brief background of scientific terms are needed for the readers who want to know the meaning of these complicated words. Briefly, the scientific term is word or phrase which conveys a specific and scientifically meaning and are only known by scientists specializing in the advanced study of a subject.

\subsection{Equivalence}

Translation equivalence defines as the communication between a word and a phrase in one language and its translation in another language (Nefale,2009:15). It represents an item in the target language that can be used to translate a specific existence of the source language item. Mabasa (2005:11) adds that in the process of supplying of equivalent terms, the term creators are faced with a lack of cohesion in the target and source languages. It is called a referential gap because the relationships between two words, actions or things are not semantically related.

\subsection{Problems of Non Equivalence}

Baker (1992: 21) defines non-equivalence as the target language has no direct equivalence for a word which occurs in the source text. There are some common problems of non-equivalence.

\section{- Culture Specific Concepts}

Based on this problem, the source-language word may express a concept that is totally unknown in the target language culture. The concept may be abstract or concrete; it may relate to a religious belief, a social custom, or even a type of food. For example, In Indonesia, there is a kind of food made of soybean called tempe. This name of food does not have any direct equivalence in English. People from foreign countries will keep calling it tempe or tempeh. It means that culture have a significance influence to the translation equivalence since in this world, there is so much culture.

- The Source Language Concept is not Lexicalized in the Target Language

It means that a concept that is known by people in some areas does not always have the lexis in every area. For example, the word savory has no equivalent in many languages, although it expresses a concept which is easy to be understood.

- The Source Language Word is Semantically Complex 
It happens when the source language word is semantically complex. Words do not have to be morphologically complex or to be semantically complex (Bolinger and Sears, 1968). A single word which consists of a single morpheme can be more complex than a whole sentence. For example is the word arruacao, a Brazillian word which means "clearing the ground under coffee trees of rubbish and piling it in the middle of the row in order to aid in the recovery of beans dropped during harvesting' (ITI News, 1988:57). Hence, a word which does not have the direct equivalence in another language will need translation to translate the word into phrase, clause or sentence.

- The Source and Target Languages Make Different Distinction in Meaning

The target language may make more or fewer different distinction in meaning than the source language. For example, in English there is only one meaning of going out in the rain. However, in Indonesian makes a distinction between going out in the rain without the knowledge that it is raining (kehujanan) and going out in the rain with knowledge that it is raining (hujan-hujanan). Therefore, each language has its own distinction in defining a word.

- The Target Language Lacks a Super Ordinate

The target language may have specific words (hyponym) but not the general one. Russian has no ready equivalent for facilities. However, it has several specific words and expressions which can be thought of as types of facilities, for example sredstva, peredvizheniya ('means of transport'), naem ('loan'), neobkhodimye pomeschcheniya ('essential accommodation'), and neobkhodimoe oborudovanie ('essential equipment'). Baker's example is Russian's lack of a super ordinate word of word facilities. However, Russia has some words, which carry meaning as some types of facilities (more specific words).

- The Target Language Lacks a Specific Term (Hyponym)

It is the opposite of the target language lacks a super ordinate. The example of this problem is English has many hyponyms under article for which it is difficult to find precise equivalents in other languages. Feature, survey, report, critique, commentary, review, and many more. Another example from Indonesian word is membawa. The word membawa has some specific term, which does not have direct equivalent in English; they are menjinjing, menyunggi, and memanggul.

- The Differences in Physical or Interpersonal Perspective

Physical or interpersonal perspective has to do with where things or people are in relation to one another, or to a place may be more important in one language than in another. For example, Japanese has six equivalents for 'give', depending on who gives to whom: yaru, ageru, morau, kureru, itadaku, and kudasaru (McCreary, 1986). Similar to Japanese, Javanese has three equivalents for eat, mangan, nedha, and dhahar. When talking to older person or younger person, someone differs whether he is talking to a younger, older person or a person in the similar age with him.

- $\quad$ The Differences in Expressive Meaning

There may be a target-language word has the same prepositional meaning as the sourcelanguage word, but has different expressive meaning. These differences in expressive meaning are usually more difficult to handle when the target-language equivalent is more emotionally loaded than the source-language item. As example, in some contexts to render the English verb batter (as in child/wife battering) by the more neutral Japanese word tataku, meaning 'to beat', plus an equivalent modifier such as 'savagely' or 'ruthlessly'.

- Difference in Form

There is no equivalence in the target language for a particular form in the source text. Certain suffixes and prefixes which convey prepositional and other types of meaning in English often have no direct equivalents in other languages. For instance, English has many couplets such as employer/employee, trainer/trainee, and payer/payee. It also makes frequent use of suffixes such as -ish (e.g. boyish, hellish, greenish) and -able (e.g. conceivable, retrievable, drinkable). Arabic, meanwhile, has no ready mechanism for producing such forms so they are often replaced by an appropriate paraphrase, depend on the meaning they convey (e.g. retrievable as 'can be retrieved' and drinkable as 'suitable for drinking').

- The Differences in Frequency and Purpose of Using Specific Forms 
Even when a particular form has a ready equivalent in the target language, there may be a difference in the frequency with which it is used or the purpose for which it is used. For example, English uses the continuous -ing form for binding clauses much more frequently than other languages which have equivalents for it, for example German and Scandinavian languages. Consequently, rendering every -ing form in an English source text with an equivalent -ing form in a German, Danish, or Swedish target text would result in stilted, unnatural style. Baker uses the example of the use of tenses, which is related to the timing system.

- $\quad$ The Use of Loan Words in the Source Text

Once a word is loaned into a particular language, we cannot control its development or its additional meaning. For example, dilettante is a loan word in English, Russian, and Japanese; but Arabic has no equivalent loan word. This means that only the prepositional meaning of dilettante can be rendered into Arabic; its stylistic effect would almost certainly have to be sacrified. Loan words also pose another problem for the unwary translator namely the problem of false friends, or faux amis as they are often called (Baker: 1992). Hence, translators should be more careful when they face the loan words in the process of translating a text.

\subsection{Translation Strategies}

Different kinds of non-equivalence require different strategies, some very straightforward, others more involved and difficult to handle. Here are some strategies used by translators for dealing with various types of non-equivalence. Based on Baker (1992), there are eight methods for translating scientific terms. Among them are translation by more general word, translation by more neutral/less expressive word, translation by cultural substitution, translation using a loan word, translation by paraphrase using a related word, translation by paraphrase using unrelated word, translation by ommission, and translation by illustration.

\section{RESEARCH METHOD}

\subsection{Data and Source of Data}

The source of data of this research was Mathematics Bilingual Textbook for junior high school students in the eighth grade. It was written by M.Cholik Adinawan and Sugijono and published by Erlangga in 2010. Indonesian language in the textbook was as the target text. The data of the research were words and phrases containing scientific terms in Mathematics Bilingual Textbook for junior high school students in the eighth grade.

\subsection{Technique of Data Collection}

The data were collected by using documentary technique. According to Bailey cited in Ahmed (2010) documentary research method refers to the analysis of documents that contains information about the phenomenon are analyzed.

\subsection{Technique of Data Analysis}

The technique of data analysis of this study used interactive model. Miles, Huberman and Saldana (2014:31) state that there are three steps used to analyze the data, they are data condensation, data display and conclusion drawing or verification.

Step one: data condensation included the process of selecting, focusing, simplifying, abstracting and transforming the words, phrases, and clauses in the mathematics bilingual textbook in order to make sure that it was really suitable as the criteria of scientific term.

Step two: after condensating the words, phrases and clauses in the textbook, the data were displaying in table to ease the readers understood the data. The data were organized from the scientific terms in mathematics bilingual textbook.

Step three: the data were concluded and verified. To draw conclusion and verify the data, it was done by studying the theory. In this study, conclusion was drawn based on table in the data display. Then verification was done by revising the data as many times as necessary.

\section{RESULT AND DISCUSSION}

Studying the mathematics bilingual textbook written by Adinawan and Sugijono, 89 specific terms were found. Among 89 terms, there were six types of problem of non- equivalence at scientific terms found in the textbook. The followings are the points of discussions needed to be made for the use of each of the problem. 
- The Source Language Concept was not Lexicalized in the Target Language

This problem occurs when the source language expresses a word which easily understood by people from other culture but it was not lexicalized. For example :

The gradient (slope) of the road can be quantified by comparing the change in the valeu of $y$ to the change in the value of $x$.

Ukuran gradien (kemiringan) jalan dapat ditentukan dengan membandingkan perubahan nilai $y$ terhadap perubahan nilai $x$.

The example shows that it cannot be found a single word in the target text which has direct equivalence with the term gradient. Therefore, the term gradient was stil translated into gradien in target language.

- The Source Language Word is Semantically Complex

A single word which consists of a single morpheme can be more complex than a whole sentence. Here is the example of single word was translated into phrase. As example :

$P=\{a, b, c, d\}$ is called a domain.

$P=\{a, b, c, d\}$ disebut daerah asal (domain).

This example indicates that the translator translated the term 'domain' into phrase 'daerah asal' but he also still maintained the term domain in target language. Therefore, a single morpheme was translated into more complex that is phrase of daerah asal (domain).

- The Target Language Lacks a Specific Term ( Hypnoym )

Usually languages tend to have general words (super ordinate) rather than the specific ones (hyponyms). Here is one of the example of the problem found in bilingual mathematic textbook.

The point $(0, c)$ is the $\boldsymbol{Y}$-intercept of the line given by $y=m x+c$.

Titik $(0, c)$ adalah titik potong garis $y=m x+c$ dengan sumbu $\mathbf{Y}$.

In analytic geometry, a y-intercept is a point where the graph of a function or relation intersects the $\mathrm{y}$-axis of the coordinate system. The target language was familiar with 'sumbu $Y$ ' rather than 'titik potong $Y$ '.

- The Differences in Expressive Meaning

There may be a target-language word which has the same prepositional meaning as the sourcelanguage word, but it may have a different expressive meaning. For instance :

Find the expanded form of each of the following expressions!

Tentukan hasil penguadratan berikut ini!

The word 'expanded form' was considered having problem of non-equivalence in which the source and target language make different distinction in meaning. since it could be described as 'being or having been enlarged or extended'. There was a clear distinction in meaning between English and Indonesian language in translating 'expanded form' into 'hasil penguadratan'.

- Difference in Form

There was often no equivalence in the target language for a particular form in the source text. Some types of meaning in English often have no direct equivalent in other languages. For instance :

Consequently, to simplify an algebraic fraction you have to recall the factorable algebraic expressions along with rules for factoring.

Hal ini berarti, untuk menyederhanakan pecahan aljabar harus diingat kembali berbagi bentuk aljabar yang dapat difaktorkan beserta aturan faktorisasinya.

- The Use of Loan Words in the Source Text

Once a word is loaned into a particular language, we cannot control its development or its additional meaning. Here is one of the example of loan word found in bilingual mathematic textbook.

Solving for a variable in terms of another variables of a linear equation.

Menyatakan suatu variabel dengan variabel lain pada persamaan linear.

The dominant problem of non equivalence found in mathematic bilingual textbook can be seen in table below. 
Table 1. Problems of Non Equivalence in Mathematic Bilingual Textbook

\begin{tabular}{lc}
\hline \multicolumn{1}{c}{ Problems of Non Equivalence } & $\begin{array}{c}\text { Total in Percentage } \\
(\mathbf{\%})\end{array}$ \\
\hline The Source Language Concept was not Lexicalized in the Target & 2.9 \\
Language & 28.9 \\
The Source Language Word is Semantically Complex & 14.5 \\
The Target Language Lacks a Specific Term (Hyponym) & 14.5 \\
The Differences in Expressive Meaning & 39,2 \\
Difference in Form & $\mathbf{1 0 0}$ \\
Total & \\
\hline
\end{tabular}

To solve the problems of non equivalence, three translation strategies proposed by Baker were applicable. The followings are the points of discussion needed to be made for the use of each of the translation strategies.

- Translation by a More General Word

In this strategy, translator may go up one level in a given semantic field to find a more general word that covers the core propositional meaning of the missing hyponym in the receptor language. For example :

For each natural number $x$ and $y$, we have shown that $(x+y)(x-y)$ can be expanded....

Untuk setiap bilangan cacah $x$ dan $y$, telah dijelaskan bahwa bentuk $(x+y)(x-y)$ dapat dijabarkan.....

- Translation by Cultural Substitution

In this strategy involves replacing an expression with a target language item, which does not have the same propositional meaning but was likely to have similar impact on the target reader. For example :

This can be done by multiplying that equation by the LCM of the denominators in the fractions.

Pengubahan ini dapat dilakukan dengan cara mengalikan setiap persamaan dengan KPK dari bilangan penyebut masing-masing pecahan.

- Translation Using a Loan Word or Loan Word Plus Explanation

Once explained, the loan word continually can be used on its own; the reader can understand without further lengthy explanation. For example :

Solving for a variable in terms of another variables of a linear equation.

Menyatakan suatu variabel dengan variabel lain pada persamaan linear.

- Translation by paraphrase Using Related Word

This strategy was used when the concept expressed by the source item is lexicalized in the target language but in different form, and when the frequency with which a certain form is used in the source text is significantly higher than would be natural in the target language. For example :

$Q=\{1,2,3,4\}$ is called a codomain.

$Q=\{1,2,3,4\}$ disebut daerah kawan (kodomain).

\section{CONCLUSION AND SUGGESTION}

After investigating the problem of non equivalence of scientific terms in Mathematic Bilingual Textbook, it is concluded that the most dominant problem of non equivalence was difference in form in translating the scientific term. In addition, some strategies were found to solve the problem of non equivalence at scientific terms are translation by a more general word, translation by cultural substitution, translation using a loan word or loan word plus explanation and translation by paraphrase using related word. Accordingly, the information gained from this study can be helpful for translators, teachers, and translation students in that to 
improve the ability to translate scientific terms. Hence, the teachers should be aware in choosing bilingual textbook for students and hopefully the next translator should transfer the source text to be fully understood by the target language reader without changing, reducing overwhelming the original meaning in the source text.

\section{References}

Ahmed, J.U. (2010). Documentary Research Method: New Dimensions. Indus Journal of Management \& Social Science (IJMSS).vol. 4 issue 1.

Ananiadou, S. (1994). A methodology for automatic term recognition. In COLING 1994 Volume 2: The 15th International Conference on Computational Linguistics (Vol. 2).

Baker, M. (1992). In Other Words: A Coursebook on Translation. London and New York: Routledge.

Miles,M.B., Huberman, A.M.\& Saldana, J. (2014). Qualitative data analysis: a methods sourcebook (3rd ed.). CA: Sage.

Nefale, S.J. (2009). The Role of Equivalence in the Creation of Terminology in Tshivenda: A Case of National Curriculum Statement in Grades R-9). Sovenga: University of Limpopo.

Newmark, P.(1988). A Textbook of Translation. Shanghai : Foreign Language Education Press.

Mabasa, T.A. (2005). Translation Equivalents for Health/ Medical Terminology in Xitsonga. Pretoria: University of Pretoria.

McCreary, D. R. (1986). Japanese-US business negotiations: A cross-cultural study. Praeger Publishers.

Pearson, A. W., Carr, J. C., \& Shaw, J. C. (2008). Toward a theory of familiness: A social capital perspective. Entrepreneurship theory and practice, 32(6), 949-969.

Popp, J., Hoag, D., \& Hyatt, D. E. (2001). Sustainability indices with multiple objectives. Ecological Indicators, $1(1), 37-47$

\section{BIOGRAPHY OF AUTHORS}

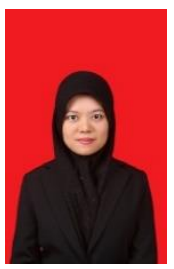

Fatin Nadifa Tarigan is currently English lecturer at Universitas Pembinaan Masyarakat Indonesia (UPMI) and an English teacher in Yayasan Perguruan Gajah Mada. She earned her master degree from English Applied Linguistics Program in Universitas Negeri Medan. Her email contact is fatinnadifa@yahoo.com.

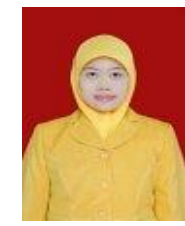

Juliana is currently English lecturer at Universitas Potensi Utama (UPU). She earned her master degree from Linguistics Program in Universitas Sumatera Utara. Her email contact is juliana.ssmsi@gmail.com. 